\title{
Good times, bad times: entrepreneurship and the business cycle
}

\author{
Juan A. Sanchis Llopis ${ }^{1}$. José María Millán ${ }^{2}$. \\ Rui Baptista $^{3,4}$ • Andrew Burke ${ }^{5}$. \\ Simon C. Parker ${ }^{6}$ - Roy Thurik ${ }^{7,8}$
}

(C) Springer Science+Business Media New York 2015

\begin{abstract}
This article introduces the special issue on Entrepreneurship and the Business Cycle, comprising articles presented at the workshop Good Times Bad Times: Entrepreneurship and the Cycle, held at the University of Valencia in November 2011. The workshop was organized to share insights about the under-researched issue of the interplay between entrepreneurship and cyclical dimensions of entrepreneurship.
\end{abstract}

Keywords Entrepreneurship - Entrepreneurship cycle - Business cycle - Business density · Unemployment · Job creation

Juan A. Sanchis Llopis

juan.a.sanchis@uv.es

1 ERI-CES and Department of Applied Economics II, Facultad de Economía, University of Valencia, Avenida dels Tarongers s/n, 46022 Valencia, Spain

2 Department of Economics, Facultad de Ciencias Empresariales, University of Huelva, Plaza de la Merced 11, 21071 Huelva, Spain

3 Brunel Business School, Brunel University London, Kingston Lane, Uxbridge UB8 2XX, UK

4 CEG-IST, University of Lisbon, Lisbon, Portugal

5 Trinity Business School, Trinity College Dublin, University of Dublin, College Green, Dublin 2, Ireland

6 Ivey Business School, Western University, 1255 Western Road, London, ON N6G 0N1, Canada

7 Erasmus School of Economic, Erasmus University Rotterdam, P.O. Box 1738, 3000 DRRotterdam, Netherlands

8 Montpellier Business School, Montpellier, France 


\section{Introduction}

Entrepreneurship is generally viewed as essential for the development of modern market economies as new firms are often the source of disruptive innovations that increase overall productivity and competitiveness. As the global economy slowly emerges from the worst financial crisis in more than six decades, the main challenge has been to ensure that recovery is accompanied by employment growth. While there is a consensus between academics and policy makers that entrepreneurship should play a fundamental role on the process of recovery and growth, the dynamics of the relationship between entrepreneurial activity and the business cycle have not yet been fully uncovered. Specifically, while a causal relationship has been suggested in some studies between entrepreneurial activity and business/employment cycles over time, research has yet to identify the existence of entrepreneurship cycles and to explain their behaviour, and the extent to which cyclical variations in entrepreneurship cycle are linked to the business cycle.

Some studies argue that entrepreneurial activity has a positive impact on economic growth (Acs et al. 2009, 2010; Carree and Thurik 2010), while others report significantly positive effects of new business formation on employment growth over time (Fritsch and Mueller 2004; Baptista and Preto 2011). On the other hand, Parker's review (2009, p. 324-330) questions whether entrepreneurship promotes long term growth, while Shane (2009) points to the high level of low ambition startups. Less is known about the relationship between entrepreneurship and the business cycle, including whether economic shocks have temporary, persistent or permanent effects on entrepreneurship (Parker 2012), and whether entrepreneurship is pro- or countercyclical, and whether entrepreneurship lags or leads the business cycle (Koellinger and Thurik 2012; Thurik 2014). In the words of one of the authors: "If shocks are persistent, rates of entrepreneurship are more sensitive to the business cycle than if shocks are temporary. In the former case, a corrective policy intervention may be warranted to return entrepreneurship back to its natural rate - especially if entrepreneurship is impacted negatively by the cycle. If shocks are permanent, however, the rate of entrepreneurship can be treated as a "random walk": cyclical shocks dominate and deterministic factors (including policy interventions) have little or no long run impact. A type of "policy neutrality" applies in this case" (Parker 2012, p. 38).

Indeed, the relationship between the business cycle and entrepreneurial activity is key for the role entrepreneurship may play in the current economic recovery from the crisis. Still, there is little evidence on how different regional environments, industry structures, and local labour markets might influence the nature of this relationship. Hence existing public policies designed to support economic recovery and job creation based on entrepreneurial incentives may be misguided.

Some recent empirical work examines the dynamic nature of causality between entrepreneurial activity and the business cycle (Thurik et al. 2008; Koellinger and Thurik 2012; Congregado et al. 2012; Parker et al. 2012a). However, these studies are conducted at a high level of aggregation, which may conceal nuanced relationships occurring at the industry, country, and regional levels. In particular, it is important to determine under which conditions - in terms of financial setting, industry composition, and human capital availability - growth-enhancing entrepreneurship might emerge from recessions, leading to economic recovery and subsequent employment growth. 
The strength of financial constraints is likely to play a key role in the interplay between business cycles and entrepreneurial activity. Economic downturns may lower the opportunity cost to start a new firm, leading to increases in new firm entry rates, therefore having a positive impact on entrepreneurship. However, this effect may be weakened because the credit crunch that accompanies financial crises raises the cost of finance and makes liquidity constraints more binding, especially if savings levels are low (Quadrini 2000).

Even if entry rates increase during economic downturns, it is not clear whether new entrepreneurial ventures are likely to stimulate a recovery. Whether they do or not likely depends on demand growth. When market demand growth is low, displacement of incumbents by entrants is a strong selection force (Baptista and Karaöz 2011), meaning that employment gains from new entrants are counterbalanced by layoffs in incumbents. For entrepreneurship to generate a positive business cycle stimulus following an economic downturn, new ventures either need to possess growth potential or to generate positive supply side spillovers on the surrounding economy.

It seems reasonable to suggest that the ability of start-ups to grow and/or generate spillovers hinges on the human capital of the founders. Founders' human capital largely determines initial conditions such as start-up size (Colombo et al. 2004) and access to credit (Åstebro and Bernhardt 2005). Founders' human capital also positively affects the success of the firm, being a major predictor of job creation (Burke et al. 2000), survival (Millán et al. 2012, 2014; Baptista et al. 2014) and growth (Bosma et al. 2004). Because recessions change labour market conditions, they are likely to impact on the profile of new entrepreneurs and the composition of their initial team. For example, Koellinger and Thurik (2012) expect that economically marginal start-ups are more prevalent during recessions, since alternative employment opportunities are scarce, and individuals faced with sudden unemployment will be more inclined to found new companies because opportunity costs to self-employment are lower. Consistent with this view, Román et al. (2011, 2013) find evidence of less entrepreneurial forms of selfemployment, such as last resort and dependent self-employment, during downturns. The key question is whether those individuals becoming entrepreneurs after the crisis do indeed have more human capital, as this will dictate whether new firms born from the crisis are more or less likely to perform well and so contribute to recovery.

The foregoing supposes that the business cycle influences entrepreneurial activity and performance by affecting profit opportunity availability and the propensity for entrepreneurs to exploit them. Both Nobel Laureate Theodore Schultz $(1975,1980)$ and Mark Casson (1982) argue that the ratio of the supply of entrepreneurs to the number of profit opportunities determines entrepreneurial economic and business performance. In other words, the economic performance that results from entrepreneurship is determined by the interaction between the demand (untapped profit opportunities) and supply (number and capability of enterprises) of entrepreneurship. Burke and van Stel (2014) operationalize this by proposing a measure of business density, namely the extent of over and under crowding of businesses in a market. They show that not only can a business density imbalance between the demand and supply of entrepreneurship affect business performance, but also that this form of disequilibrium can be cyclical and persistent.

This research highlights the need for greater exploration of the existence and impact of business density cycles. Thus, if there are insufficient able entrepreneurs to exploit 
untapped profit opportunities (a business density undershoot), will this lead to suboptimal economic performance? Or by contrast in a business density overshoot (over crowded market), do too many entrepreneurs try to exploit untapped market opportunities to the point of wasting economic and human resources? Affirmative answers to both of these questions would in turn raise the question of whether the scale of enterprise policy aimed at stimulating the supply of entrepreneurs ought to run counter to cycles in business density. Early models on the influence of the gap between the actual industrial structure and some 'optimal' one in terms of small firm presence and number of business owners can be found in Audretsch et al. (2002) and Carree et al. (2007), respectively.

This special issue on cyclical dimensions of entrepreneurship has been motivated by several gaps in the scholarly literature. While the papers in this special issue advance the frontiers of knowledge in this area, our real intention is to provide a critical mass of new research on entrepreneurial cyclicality that can be used as a platform for future research on the topic. In the next section of the paper we provide an overview of the papers in the special issue in terms of a series of adapted abstracts. This is followed by a conclusion where, building on the issues identified by Parker (2012), we will focus on the four following questions: First, is there persistence in entrepreneurship? Second, is entrepreneurship pro- or counter-cyclical? Third, do business cycles influence entrepreneurship and/or are they influenced by entrepreneurship? Fourth, do start-up incentives during recessions pay off?

\section{Review of the papers in the special issue}

This issue contains eight papers, most of which were first presented in a preliminary version at the workshop Good Times Bad Times: Entrepreneurship and the Cycle (Valencia, November 2011). From the collection of papers, three provide analyses for a group of countries (Klapper et al. provide evidence on 109 countries; Scholman et al. on 19 OECD countries; and Millán et al. on the EU-15). Of the remaining papers, two use Spanish micro data (Añón-Higón et al. and Beneito et al.), one uses German data (Fritsch et al.), and one uses US data (Burke and Shaukat). Finally, Faria presents a theoretical model without using data.

Faria's paper provides a theoretical framework, which can explain the results obtained by Koellinger and Thurik (2012) and Congregado et al. (2012), i.e., for the existence of reverse causality between entrepreneurial activity and the business cycle. In particular, Faria presents an extended Ramsey model that relates entrepreneurship dynamics to unemployment and output dynamics. According to this model, when unemployment is high, unemployed individuals may choose to become entrepreneurs and enter the market introducing a new technological innovation. This increases the capital stock leading to the creation of new jobs, raising output and consumption. When the economy is booming and unemployment is low, the number of new entrepreneurs shrinks leading to a fall in technological innovations and capital stock, which will result in a reduction of employment, output and consumption, and the cycle recurs.

In the next paper, Fritsch et al. identify a positive - and hence, countercyclical relationship between unemployment rates and start-up activities in Germany. New business formation is observed to be higher during recessions than in boom periods. 
The authors analyse the periods of low and high unemployment and find that the effect of unemployment on new business formation is only statistically significant if the level of unemployment is below 'normal', i.e., below the trend. This means that start-up activities are relatively low in times where relatively many employment opportunities are available while unemployment above the trend does not significantly induce more start-ups. This finding contrasts with conventional notions of 'unemployment push' driving entries to entrepreneurship when employment opportunities are scarce.

By contrast, Klapper et al.'s paper finds evidence of a pro-cyclical relationship between the business cycle (GDP growth) and entrepreneurship (new firm registrations) by using data covering more than hundred countries over the period 2002-2012, which include pre-crisis, crisis, and recovery periods related to the global financial crisis. They observe how country-level differences in financial development and the business environment influence the strength of this relationship. In particular, higher levels of financial development and a better business climate seem to be associated with a stronger pro-cyclicality of entrepreneurship over time, both across countries and within countries, i.e., a sharper contraction of new firm registrations at the outset of a recession, and a faster recovery of new firm registrations after the recession has ended.

Scholman et al. analyze the interplay among entrepreneurial activity, business cycles and unemployment in relation to economic openness. Using data for 19 OECD countries, the authors find that in the short run (after one quarter), a country's entrepreneurial activity is stimulated when its business cycle is lagging the world's business cycle, whereas in the medium run (after 1 to 2 years), entrepreneurial activity is stimulated when its business cycle is leading the world's business cycle. These results suggest that a country's business cycle relative to the world cycle creates different types of entrepreneurial opportunities depending on the time horizon considered. However, this evidence only applies to relatively open economies, suggesting that economic openness plays a role for entrepreneurial opportunities related to a country's cyclical performance.

The relation between the business cycle and self-employed individuals' ability to create new jobs, and its underlying determinants, is analysed in Millán et al. Using micro data for the EU-15, this paper studies the effect of the business cycle on the individual decision of self-employed without employees (i.e., own-account workers) to hire their first employees. Millán et al. observe that hiring decisions are less likely to occur during recessions, which suggests a pro-cyclical relationship. Next, they search for the possible mechanisms behind this relationship and find that liquidity constraints and the existence of previous spells as unemployed (both elements being more common during recessions) reduce the probability of transitioning from being an own-account worker to an employer.

Using panel data for Spanish manufacturing, Añón-Higón et al. and Beneito et al. study the role of R\&D activities carried out by SMEs and its relation with the business cycle. On the one hand, Beneito et al. extend the analysis of Aghion et al. (2012) to explore the effect of ownership on the response of firms' R\&D expenditures to the business cycle. They find that firms' R\&D spending is countercyclical but that credit constraints may reverse this counter cyclicality. Moreover, these results are likely to be moderated by firms' ownership structure. In particular, among firms that are family owned or are group affiliated, the responsiveness of R\&D to the business cycle is considerably lower, especially if they are credit constrained during recessions. On the 
other hand, Añón-Higón et al., analyse whether undertaking R\&D activities allows SMEs to attenuate the negative impact of the recessionary phases of the cycle on productivity. They find that $R \& D$ activities help to alleviate the negative effects of downturns on productivity. Furthermore, they find that SMEs' R\&D productivity premium in recessions doubles that in expansions, suggesting a countercyclical effect upon SMEs' productivity over the business cycle.

Finally, Burke and Shaukat analyse the impact of business density cycles on business establishment entry and exit in the USA. They explore the behaviour of businesses in disequilibrium when there is a mismatch between the supply of entrepreneurs and the availability of untapped profit opportunities, which they seek to exploit. In contrast to orthodox economic theory, where both entry and exit are assumed to play equilibrating roles in disequilibrium, they find that in disequilibrium entry is dis-equilibrating, while firm closure is equilibrating. In other words, entry rates are observed to increase when the actual number of establishments is above the equilibrium number (an overshoot) and decrease when it is below the equilibrium number (undershoot). In contrast, exit plays an equilibrating role by accelerating in an overshoot and slowing down in an undershoot situation. This highlights that the process in which the supply of entrepreneurs responds to the availability of untapped profit opportunities is costly and slow.

\section{Conclusion}

Four questions seem to emerge from the recent literature. First, is there persistence in entrepreneurship? Persistent effects are reported in Parker et al. (2012a, b), Burke and van Stel (2014) and Millán et al. (2014) while some permanent effects are found in Congregado et al. (2012a). Second, is entrepreneurship pro- or counter-cyclical? Román et al. (2011, 2013) conclude that the emergence of more entrepreneurial forms of self-employment evolve pro-cyclically whereas other forms including last-resort or dependent self-employment evolve counter-cyclically. The former result is in line with those of Koellinger and Thurik (2012). See also Parker (2012) for a discussion. Third, do business cycles influence entrepreneurship and/or are they influenced by entrepreneurship? Both Parker et al. (2012b) and Koellinger and Thurik (2012) find evidence for both influences at the empirical level. And fourth, do start-up incentives during recessions pay off? A brief literature survey of recent empirical and conceptual work shows mixed results. See Román et al. (2011, 2013), Congregado et al. (2010), Millán et al. (2014), Shane (2009), Caliendo and Künn (2011) and Koellinger and Thurik (2012). See also the review of Parker (2012).

Interpreting the eight papers of the current issue in terms of these four questions we come to the following conclusions. Firstly, Faria's paper is related to all questions using a simple and intuitive theoretical framework: entrepreneurship and technological innovations mitigate high unemployment situations while low unemployment situations discourage innovations. Hence, entrepreneurship is viewed as (counter-)cyclical rather than persistent (questions 1 and 2). Furthermore, entrepreneurial and unemployment cycles are supposed to cause business cycles (question 3), so start-up incentives seem to be an appropriate counter-recession policy response (question 4).

The remaining papers focus on particular aspects of these four questions. Burke and Shaukat provide evidence of persistence of business establishments in their study of 
cycles in business density (question 1). Entry and exit have asymmetric effects as business establishment entry increases when the number of establishments is above equilibrium and slows down when this number is below equilibrium - whereas exit does the reverse.

Many papers in this issue deal with the interplay between business cycles and entrepreneurial activity (question 2). Fritsch et al. find a different impact of the cycle on start-up activities depending on whether unemployment is below or above the trend. Klapper et al. report evidence of how country-level differences in financial development and the business environment can influence the strength of this relationship. Scholman et al. suggest that a country's business cycle relative to the world cycle (i.e., lagging or leading) creates different types of entrepreneurial opportunities depending on the time horizon considered. Millán et al. highlight the importance of financial constraints for the relationship between cycle and job creation by the smallest SMEs, and suggest the need to facilitate access to credit for these firms in order to mitigate the negative consequences of recessions on job creation. Añón-Higón et al. find that R\&D activities alleviate the negative effects of downturns on productivity and that the productivity premium is higher in recessions as compared to expansions. Finally, Beneito et al. concentrate on the moderating effect of different firms' ownership types on the responsiveness of R\&D spending to the business cycle.

Only Faria deals with question 3 in that his model predicts that entrepreneurial and unemployment cycles cause business cycles.

Finally, in relation to question 4, some interesting insights can be found in Klapper et al. and Millán et al. Klapper et al. observe that the number of start-ups decreases during recessions, especially in those countries with higher levels of financial development and better business environments. Hence, their results point to the positive effects start-up incentives may have in these countries during recessions. For their part, Millán et al. identify previous spells of unemployment as mechanism behind the negative relationship between the cycle and job creation. They go on to consider formal education and prior work experience as possible admission criteria for individuals applying for participation in start-up incentive programs.

Acknowledgments Early versions of most papers of this issue were presented at the Workshop Good Times Bad Times: Entrepreneurship and the Cycle (Valencia, Spain; November 2011). Guest Editors gratefully acknowledge the effort of reviewers for their valuable comments and suggestions that made a significant difference in the development of the manuscripts. Special thanks go to the former and current editors of International Entrepreneurship and Management Journal - Domingo Ribeiro and Salvador Roig - for their support. We acknowledge funding from the Spanish Ministry of Economy and Competitiveness (projects ECO2011-25033, ECO2011-30323-C03-02 and ECO2013-43526-R,), the Generalitat Valenciana (Project PROMETEOII/2014/054) and Fundación BBVA (Project 2014).

\section{References}

Acs, Z. J., Audretsch, D. B., Braunerhjelm, P., \& Carlsson, B. (2009). The knowledge spillover theory of entrepreneurship. Small Business Economics, 32(2), 15-30.

Acs, Z. J., Audretsch, D. B., Braunerhjelm, P., \& Carlsson, B. (2010). The missing link: knowledge diffusion and entrepreneurship in endogenous growth. Small Business Economics, 34(1), 105-125. 
Aghion, P., Askenazy, P., Berman, N., Cette, G., \& Eymard, L. (2012). Credit constraints and the cyclicality of R\&D investment: evidence from France. Journal of the European Economic Association, 10(5), 10011024.

Åstebro, T., \& Bernhardt, I. (2005). The Winner's curse of human capital. Small Business Economics, 24(1), 63-78.

Audretsch, D. B., Carree, M. A., van Stel, A. J., \& Thurik, A. R. (2002). Impeded industrial restructuring: the growth penalty. Kyklos, 55(1), 81-97.

Baptista, R., \& Karaöz, M. (2011). Turbulence in growing and declining industries. Small Business Economics, 36(3), 249-270.

Baptista, R., \& Preto, M. T. (2011). New firm formation and employment growth: regional and business dynamics. Small Business Economics, 36, 419-442.

Baptista, R., Karaöz, M., \& Mendonça, J. (2014). The impact of human capital on the early success of necessity versus opportunity-based entrepreneurs. Small Business Economics, 42(4), 831-847.

Bosma, N. S., van Praag, C. M., Thurik, R., \& de Wit, G. (2004). The value of human and social capital investments for the business performance of startups. Small Business Economics, 23(3), 227-236.

Burke, A., \& van Stel, A. (2014). Entry and exit in disequilibrium. Journal of Business Venturing, 29(1), 174 192.

Burke, A. E., FitzRoy, F. R., \& Nolan, M. (2000). When less is more: distinguishing between entrepreneurial choice and performance. Oxford Bulletin of Economics and Statistics, 5, 565-587.

Caliendo, M., \& Künn, S. (2011). Start-up subsidies for the unemployed: long-term evidence and effect heterogeneity. Journal of Public Economics, 95(3-4), 311-331.

Carree, M. A., \& Thurik, A. R. (2010). The impact of entrepreneurship on economic growth. In D. B. Audretsch \& Z. J. Acs (Eds.), Handbook of entrepreneurship research (pp. 557-594). Berlin: Springer Verlag.

Carree, M. A., van Stel, A., Thurik, A. R., \& Wennekers, S. (2007). Economic development and business ownership revisited. Entrepreneurship and Regional Development, 19(3), 281-291.

Casson, M. (1982). The entrepreneur: An economic theory. Oxford: Martin Robertson.

Colombo, M., Delmastro, M., \& Grilli, L. (2004). Entrepreneurs' human capital and the start-up size of new technology-based firms. International Journal of Industrial Organization, 22, 1183-1211.

Congregado, E., Golpe, A. A., \& Carmona, M. (2010). Is it a good policy to promote self-employment for Job creation? Evidence from Spain. Journal of Policy Modeling, 32(6), 828-842.

Congregado, E., Golpe, A. A., \& Parker, S. C. (2012). The dynamics of entrepreneurship: hysteresis, business cycles and government policy. Empirical Economics, 43(3), 1239-1261.

Fritsch, M., \& Mueller, P. (2004). Effects of New business formation on regional development over time. Regional Studies, 38(8), 961-975.

Koellinger, P. D., \& Thurik, R. (2012). Entrepreneurship and the business cycle. Review of Economics and Statistics, 94(4), 1143-1156.

Millán, J. M., Congregado, E., \& Román, C. (2012). Determinants of self-employment survival in Europe. Small Business Economics, 38(2), 231-258.

Millán, J. M., Congregado, E., \& Román, C. (2014). Persistence in entrepreneurship and its implications for the European entrepreneurial promotion policy. Journal of Policy Modeling, 36(1), 83-106.

Parker, S. C. (2009). The economics of entrepreneurship. Cambridge: Cambridge University Press.

Parker, S.C. (2012). Entrepreneurship and the Business Cycle: Evidence and Implications for Policy Makers. In Braunerhjelm, P. (Ed.), Swedish Economic Forum Report 2012. Entrepreneurship, Norms and the Business Cycle, Chapter 2, 35-51.

Parker, S. C., Congregado, E., \& Golpe, A. A. (2012a). Testing for hysteresis in entrepreneurship in 23 OECD countries. Applied Economics Letters, 19(1), 61-66.

Parker, S. C., Congregado, E., \& Golpe, A. A. (2012b). Is entrepreneurship a leading or lagging indicator of the business cycle? Evidence from UK self-employment data. International Small Business Journal, 30(7), 736-753.

Quadrini, V. (2000). Entrepreneurship, saving, and social mobility. Review of Economic Dynamics, 3(1), 1-40.

Román, C., Congregado, E., \& Millán, J. M. (2011). Dependent self-employment as a way to evade employment protection legislation. Small Business Economics, 37(3), 363-392.

Román, C., Congregado, E., \& Millán, J. M. (2013). Start-up incentives: entrepreneurship policy or active labor market program? Journal of Business Venturing, 28(1), 151-175.

Schultz, T. W. (1975). The value of the ability to deal with disequilibria. Journal of Economic Literature, 13(3), 827-846.

Schultz, T. W. (1980). Investment in entrepreneurial ability. Scandinavian Journal of Economics, 82(4), 437448. 
Shane, S. (2009). Why encouraging more people to become entrepreneurs is Bad public policy. Small Business Economics, 33(2), 141-149.

Thurik, A.R. (2014). Entrepreneurship and the Business Cycle, IZA World of Labor, 90, doi:10.15185/izawol. 90

Thurik, R., Carree, M., van Stel, A., \& Audretsch, D. B. (2008). Does self-employment reduce unemployment? Journal of Business Venturing, 23(6), 673-686. 